\title{
Variations in Parameters of Liver Function and Plasma Progesterone Related to Underfeeding and Ketosis in a Dairy Herd
}

\author{
By E. Ropstad, K. Halse and A. O. Refsdal \\ Department of Reproductive Physiology and Pathology \\ and Department of Biochemistry, Norwegian College of Veterinary Medicine, Oslo, \\ and Norwegian Red Cattle Association, Hamar.
}

\begin{abstract}
Ropstad E., K. Halse and A. O. Refsdal: Variations in parameters of liver function and plasma progesterone related to underfeeding and ketosis in a dairy herd. Acta vet. scand. 1989, 30, 185-197. - Twenty-eight Norwegian Red Cattle dairy cows were fed silage ad libitum and restricted amounts of concentrates. Blood samples were collected before morning feeding, once or twice weekly, from 2 weeks before to 12 weeks after calving. Parameters of liver function, carbohydrate status and fertility were recorded in order to assess their interrelationships.

Eight cows were treated for clinical ketosis. Four of these had to be treated 2 or 3 tımes. Aspartate aminotransferase and bilirubın showed the highest within-animal coefficients of correlation with acetoacetate. Analysis of variance revealed a significant effect of carbohydrate status (indicated by plasma acetoacetate levels) on the levels of aspartate aminotransferase, glutamate dehydrogenase and sorbitol dehydrogenase, though only a small part of the total variation was explained by this factor. The estimated volume density of liver fat in the 4th week of lactation averaged $6.0 \pm 6.4 \%( \pm \mathrm{SD})$ ranging from $0.1-25.1 \%$. Liver fat content at this stage of lactation was not significantly correlated with other indicators of liver function or carbohydrate status. Cows treated for clinical ketosis had significantly lower plasma progesterone values at the time of first ketosis treatment than untreated multıparous cows. The frequency of high progesterone values $(>3 \mathrm{ng} / \mathrm{ml})$ being significantly lower in treated than in untreated cows during the period from 3-5 weeks post partum, though not at later stages. In conclusion, the results revealed a significant relationship between carbohydrate status and liver function, and also between clinical ketosis and luteal function.
\end{abstract}

glucose; free fatty acids; aspartate aminotransferase; glutamate dehydrogenase; sorbitol dehydrogenase; bilirubin; bile acids.

\section{Introduction}

When considering the etiology of ketosis in dairy cows attention has been given to liver function. This is because of the frequently observed accumulation of fat in this organ, and the variations in liver-specific blood characteristics found in affected animals. Saarinen \& Shaw (1950) found that the concentration of liver lipids could be relatively normal in early stages of spontaneous keto- sis. In contrast, Roberts et al. (1981) suggested that fat accumulation may be accompanied by liver damage and predispose for ketosis.

A study of the literature reveals some discrepancies between authors concerning the extent to which different liver-specific parameters are affected in ketosis (Kauppinen 1984, Gröhn et al. 1983, Pehrson 1966) and the hypothesis that liver damage is a pri- 
mary cause of ketosis has apparently not been substantiated.

In the present study, liver function parameters were measured regularly during the first 3 months of lactation in individually-fed experimental animals with a high incidence of clinical ketosis (about $30 \%$ ), the condition being apparently due to underfeeding.

The findings obtained on studying individual cows for prolonged periods of time may serve to supplement previous field studies which have been mainly concerned with differences between individuals.

During the study, plasma progesterone levels in the cows were measured, and records were kept of the animal's reproductive performance. The idea was to provide material for comparison with reports in the literature of reproductive disorders related to underfeeding, and the development of ketosis and/or fatty liver (Rowlands \& Reld 1982, Refsdal 1977, Roine \& Saloniemi 1978).

\section{Materials and methods}

\section{Animals and feeding}

Twenty-eight Norwegian Red Cattle dairy cows, fed on grass silage ad libitum, were randomly assigned to a $2 \times 2$ factorial feeding experiment involving differences in the

\footnotetext{
Abbreviations used:

BA = bile acids

FFA $=$ free fatty acids

ASAT = aspartate aminotransferase

GLDH = glutamate dehydrogenase

SDH = sorbitol dehydrogenase

GLUC = glucose

ACAC $=$ acetoacetate

BILI = total bilirubin

DCP = digestible crude proteln

PROG = progesterone

FFU = fattenıng feed units

BSP = sulfobromophthalein

BSP $1 / 2=$ half-life of sulfobromophthalein in plasma
}

total amount and protein content of the concentrate offered.

Two high-protein groups $(\mathrm{Hp})$ received concentrates with $17.5 \%$ of digestible crude protein either in substandard (low energy, Le) or approximately standard (high energy, $\mathrm{He}$ ) amounts. Corresponding $\mathrm{Le}$ and $\mathrm{He}$ groups were established with cows on lowprotein $(\mathrm{Lp})$ concentrates with $12.5 \%$ DCP. Concentrate rations were calculated assuming a silage consumption of about $50 \mathrm{~kg}$ per day. Since the average amount actually eaten was 10 to $15 \mathrm{~kg}$ below this level, even $\mathrm{He}$ animals were underfed to some extent.

After calving the concentrate rations were increased over a period of 2 weeks from 3 $\mathrm{kg} /$ day to 5 (Le), or $8 \mathrm{~kg} /$ day (He) (multiparous cows) or from $3 \mathrm{~kg} /$ day to 4 (Le) or 6 $\mathrm{kg} /$ day $(\mathrm{He})$ (heifers). After the second week of lactation, daily concentrate rations were adjusted according to milk yields, with 0.4 $\mathrm{kg}$ being fed per $\mathrm{kg}$ of milk exceeding $20 \mathrm{~kg}$ per day, in addition to the basal allowance of $1.5 \mathrm{~kg}$ (Le-cows) or $5 \mathrm{~kg}$ (He group). Heifers received basal allottments of $2 \mathrm{~kg}$ (Le) or $4.9 \mathrm{~kg}(\mathrm{He})$ with $0.4 \mathrm{~kg}$ increments per $\mathrm{kg}$ of milk above $16 \mathrm{~kg} /$ day.

Individual feed consumption was recorded daily and milk yields 3 days per week. Grass silage analyses were performed monthly on pooled samples taken at 2-week intervals. Average values for yield, feed intake and energy balance during the period from 2-8 weeks after calving are shown in Table 1.

The cows calved from early September to the beginning of April. Seven of the 21 multiparous animals required treatment for ketosis (4 in the Le-groups and 3 in the Hegroups). Of the 7 heifers, 1 received treatment for ketosis (Le-group). The post partum timing of the cases seemed to be as in the field, 6 first treatments being given between the 11 th and the 21 st day in milk. This early onset, even before the group dif- 
ferences had been established, indicates that the slow rate at which feed rations were increased during the first fortnight after calving was of etiological importance. In addition, 1 cow was treated for the first time 34 days post partum, while the heifer case occurred on the 66th day of lactation. Four of the sick cows were treated 2 or 3 times at intervals ranging from 7 to 17 days. The high relapse rate could have been due to the fact that levels of energy intake were not increased after first treatment.

Cows suffering from clinical ketosis received treatment with $150 \mathrm{mg}$ prednisolone acetate, injected intramuscularly. Supplementary, oral treatment with sodium proprionate was given for the following 5 days.

\section{Blood samples}

Using heparinized vacutainers, blood samples were collected from the jugular vein at 6 a. $\mathrm{m}$. before morning feeding twice weekly from calving until 12 weeks after calving. The samples were centrifuged immediately after collection. While awaiting analysis, the plasma was stored at $-196^{\circ} \mathrm{C}$ for ACAC and GLUC assays, at $-80^{\circ} \mathrm{C}$ for ASAT, GLDH, SDH, FFA, BILI and BA assays, and at $-20^{\circ} \mathrm{C}$ for the PROG assay. ASAT, GLDH, SDH, FFA, BILI and BA were determined in 1 sample only per week.

Plasma ACAC and GLUC were determined by the methods described by Blom \& Halse (1975). Except for ACAC, GLUC and PROG, all analyses were carried out in a centrifugal analyzer (Gemsaec Fast Analyzer from Elektro-Nucleonics Inc.). Control sera or pooled sera were used to monitor the day-to-day repeatability. BA were determined using a modification of the commercial kit Enzabile as described by Hauge \& $A b$ delkader (1984). The activity of ASAT (reagents from Baker Chemicals, Netherlands) was determined according to the recommen- dations of the Committee on Enzymes of the Scandinavian Society for Clinical Chemistry and Clinical Physiology. Activities of GLDH and SDH and the levels of BILI were determined using commercial kits (from Boehringer, Fed Rep. of Germany) appropriate for the Gemsaec Analyzer. All enzyme activities, expressed as units ( $\mu \mathrm{mol} /$ min) per liter were determined at $37^{\circ} \mathrm{C}$. FFA were assayed by the acyl-CoA synthetaseacyl CoA oxidase method (reagents from Wako Chemicals, Fed. Rep. of Germany).

\section{Liver samples}

Liver samples were collected from cows in the fourth week of lactation by percutaneous needle biopsy through the 11 th intercostal space. The liver tissue was fixed in a $3 \%$ glutaraldehyde solution in a $0.1 \mathrm{mmol} / 1 \mathrm{ca}-$ codylate buffer. Following fixation, biopsies were cut into small tissue blocks $(<0.5 \mathrm{~mm}$ diam.), post-fixed in a $2 \%$ osmium tetroxide solution, dehydrated in acetone and embedded in Araldite ${ }^{\circledR}$.

Two Araldite-embedded blocks of liver tissue from each cow were selected at random, and 1 semi-thin section cut from each block. Sections were stained with a $1 \%$ toluidine blue solution in saturated sodium bicarbonate. Three photo micrographs were taken of randomly chosen areas in each section and printed to a final magnification of 1000 diameters. On the micrographs, a grid with coarse and fine points, ratio 1:36 (fine points separated by $5 \mathrm{~mm}$ ) was used to estimate the volume density of liver fat. A total of 720 points were counted for each cow.

\section{BSP-test}

Sulfobromophthalein $(3 \mathrm{mg} / \mathrm{kg})$ was injected intravenously in the 4 th week of lactation. Blood samples were collected from the opposite jugular vein before injection and every 2-3 $\mathrm{min}$ for a period of $20 \mathrm{~min}$ after 
injection. BSP-concentration and the halflife of sulfobromophthalein in plasma (BSP 1/2) were determined as described by Cornelius (1980). Results (BSP 1/2) are given in min.

\section{Reproductive parameters}

The animals were inspected for signs of oestrus twice daily. Rectal palpation was performed once weekly and pregnancy diagnosis was performed by rectal palpation at 5-6 weeks after service. The plasma concentrations of progesterone were measured twice weekly (Benjaminsen \& Karlberg 1981).

\section{Grouping of cows}

The cows were divided into 3 categories according to age and clinical signs of ketonemia. Multiparous cows treated for clinical ketosis (ketosis, $\mathbf{n}=7$ ) were compared to multiparous cows which did not receive ketosis treatment (multiparous controls) and non-treated heifers $(n=6)$. Since only 1 heifer received ketosis treatment (as late as 66 days post partum), this animal was excluded from comparisons between animal groups.

\section{Statistical methods}

Statistical analysis was performed by $S A S$ (1982) programmes. Differences among means were assessed using the Wilcoxon two-sample test. The data were analyzed by linear models which accounted for the effects of metabolic status indicated by the values of ACAC, the week of lactation (1, 2 . .. . 12), the mean precalving levels of the dependent variables, and the age of the cows indicated by number of lactation ( 1 and $>$ 1). To obtain a better approximation to normal distribution, log transformations of dependent variables were used when the data were subjected to analysis of variance. The variance contribution or the percent of total sum of squares (SS), was calculated for each independent variable from its SS divided by total SS; i.e. (Type III SS/Total SS) $\times 100$. Correlation analysis (Spearman correlation coefficient) was used to assess relationships between selected parameters. In addition, findings were subjected to chi-square tests.

\section{Results}

Ketone levels

Plasma ACAC averaged $1.76 \pm 0.92( \pm$ SD) $\mathrm{mmol} / \mathrm{l}$ (Fig. 1 and Table 1 ), range $0.58-2.93 \mathrm{mmol} / \mathrm{l}$, at the time of first ketosis treatment and glucose $2.56 \pm 0.32 \mathrm{mmol} / 1$ (Fig. 1), and $1.69 \pm 0.96( \pm \mathrm{SD}) \mathrm{mmol} / \mathrm{l}$ (GLUC mean $\pm \mathrm{SD}: 2.81 \pm 0.25 \mathrm{mmol} / \mathrm{l}$ ) immediately before a second or third treatment (Fig. 1). Average plasma ACAC values in ketosis-treated cows remained above 0.1 $\mathrm{mmol} / \mathrm{l}$ during the first 9 weeks of lactation. Thereafter, in the third month of lactation, all categories of animals showed low ACAC averages, values $(\mathrm{mmol} / \mathrm{l})$ being $0.05 \pm 0.05$ ( \pm SD), 0.04 and 0.03 for ketosis-treated animals, and the Le and He controls, respectively.

\section{Feed consumption and energy balance}

Silage intake and milk yields were both significantly lower in cows treated for ketosis than in the controls. Le-controls showed the lowest energy balance during the first 7 weeks of lactation (Table 1). Average energy balances remained negative in ketotic animals and in Le-controls also after the 9th week of lactation. Energy balances during this period were $-3.49 \mathrm{FFU} /$ day, -3.02 FFU/day and -0.14 FFU/day for Le-controls, ketosis-treated cows and He-controls, respectively.

Metabolic status and parameters of liver function

The within-animal coefficients of correlation between indicators of liver function 
Table 1. Feed consumption, milk yield and plasma parameters. Averages for the first 8 weeks after calving. Values for 7 multiparous cows with ketosis compared to multiparous controls (He 8 and Le 6 animals) and to 6 healthy heifers.

\begin{tabular}{|c|c|c|c|c|}
\hline \multirow{3}{*}{ Varables } & \multicolumn{4}{|c|}{ Mean values 1 ) } \\
\hline & \multirow[t]{2}{*}{ Ketosis } & \multicolumn{2}{|c|}{ Multiparous controls } & \multirow[t]{2}{*}{ Helfers } \\
\hline & & $\mathrm{He}$ & Le & \\
\hline Number of animals & 7 & 8 & 6 & 6 \\
\hline Silage intake, $\mathrm{kg} /$ day & $33.1^{\mathrm{a}}$ & $41.3^{b}$ & $39.0^{\mathrm{b}}$ & $27.4^{\mathrm{c}}$ \\
\hline Concentrate intake, $\mathrm{kg} / \mathrm{day}$ & $4.9^{\mathrm{a}}$ & $8.2^{b}$ & $3.7 \mathrm{c}$ & $5.7^{\mathrm{a}}$ \\
\hline Fat corrected milk, $\mathrm{kg} /$ day & $21.4^{\mathrm{a}}$ & $29.2^{\mathrm{c}}$ & $25.3^{b}$ & $22.5^{\mathrm{ab}}$ \\
\hline Energy balance, FFU/day & $-3.4^{a}$ & $-1.9^{b}$ & $-4.8^{c}$ & $-3.0^{\mathrm{a}}$ \\
\hline Acetoacetate, $\mathrm{mmol} / \mathrm{l}$ & $0.65^{\mathrm{a}}$ & $0.07^{b}$ & $0.19 c$ & $0.07^{b}$ \\
\hline Glucose, $\mathrm{mmol} / \mathrm{l}$ & $3.35^{\mathrm{a}}$ & $4.10^{\mathrm{b}}$ & $3.78^{\mathrm{c}}$ & $4.16^{b}$ \\
\hline Free fatty acids, $\mu \mathrm{mol} / 1$ & $484^{a}$ & $378^{a}$ & $607^{b}$ & $570^{\mathrm{ab}}$ \\
\hline Aspartate aminotransferase, $U / 1$ & $136^{\mathrm{a}}$ & $78^{b}$ & $81^{\mathrm{b}}$ & $79 \mathrm{~b}$ \\
\hline Glutamate dehydrogenase, $\mathrm{U} / 1$ & $61^{\mathrm{a}}$ & $37^{\mathrm{ab}}$ & $16^{b}$ & $56^{a}$ \\
\hline Sorbitol dehydrogenase, U/1 & $16^{\mathrm{a}}$ & $10^{b}$ & $7 \mathrm{~b}$ & $12^{\mathrm{ab}}$ \\
\hline Total bilirubin, $\mathrm{mmol} / \mathrm{l}$ & $2.2^{\mathrm{b}}$ & $1.4^{\mathrm{a}}$ & $2.7^{b}$ & $2.8^{\mathrm{b}}$ \\
\hline Total bile acids, $\mu \mathrm{mol} / 1$ & $78^{a}$ & $99 a$ & $66^{a}$ & $170^{\mathrm{b}}$ \\
\hline
\end{tabular}

1) Means within rows with different superscript differ significantly $(\mathrm{p}<0.05)$.

Table 2. Analysis of variance. Plasma characteristics during the first three months of lactation as a function of independent variables, linear models. The results are based on the response of 28 cows repeatedly sampled once (aspartate aminotransferase, glutamate dehydrogenase, sorbitol dehydrogenase, bile acids, free fatty acids, bilirubin) or twice (acetoacetate, glucose) weekly during the first 3 months of lactation.

\begin{tabular}{lccccc}
\hline & \multicolumn{5}{c}{ Percent of total sum of squares1) } \\
\cline { 2 - 5 } & \multicolumn{5}{c}{ Partial effects } \\
\cline { 2 - 5 } $\begin{array}{l}\text { Dependent } \\
\text { varables }\end{array}$ & $\begin{array}{l}\text { Aceto- } \\
\text { acetate }\end{array}$ & $\begin{array}{c}\text { Week of } \\
\text { lactation }\end{array}$ & $\begin{array}{l}\text { Mean precalving } \\
\text { levels of the } \\
\text { dependent varable }\end{array}$ & Age2) & Model \\
\hline Glucose & $42.8^{\mathrm{c}}$ & $9.9^{\mathrm{ns}}$ & $0.5^{\mathrm{b}}$ & $0.8^{\mathrm{c}}$ & $61.7^{\mathrm{c}}$ \\
Free fatty acids & $11.3^{\mathrm{c}}$ & $17.9^{\mathrm{c}}$ & $3.4^{\mathrm{c}}$ & $1.9^{\mathrm{b}}$ & $49.6^{\mathrm{c}}$ \\
Aspartate aminotransferase & $11.7^{\mathrm{c}}$ & $1.4^{\mathrm{ns}}$ & $9.1^{\mathrm{c}}$ & $0.2^{\mathrm{ns}}$ & $26.9^{\mathrm{c}}$ \\
Glutamate dehydrogenase & $2.6^{\mathrm{b}}$ & $4.8^{\mathrm{ns}}$ & $2.8^{\mathrm{b}}$ & $3.3^{\mathrm{b}}$ & $11.7^{\mathrm{b}}$ \\
Sorbitol dehydrogenase & $1.2^{\mathrm{ns}}$ & $5.5^{\mathrm{ns}}$ & $9.8^{\mathrm{c}}$ & $2.6^{\mathrm{b}}$ & $16.8^{\mathrm{c}}$ \\
Bile acids & $0.0^{\mathrm{ns}}$ & $6.7^{\mathrm{a}}$ & $1.2^{\mathrm{ns}}$ & $5.3^{\mathrm{c}}$ & $12.8^{\mathrm{c}}$ \\
Bilirubin & $6.4^{\mathrm{c}}$ & $10.9^{\mathrm{c}}$ & $3.3^{\mathrm{b}}$ & $4.9^{\mathrm{c}}$ & $27.4^{\mathrm{c}}$ \\
\hline
\end{tabular}

1) Level of significance: a) $\mathrm{p}<0.05$, b) $\mathrm{p}<0.01$, c) $\mathrm{p}<0.001$.

2) No. of lactation $=1$ or $>1$. 

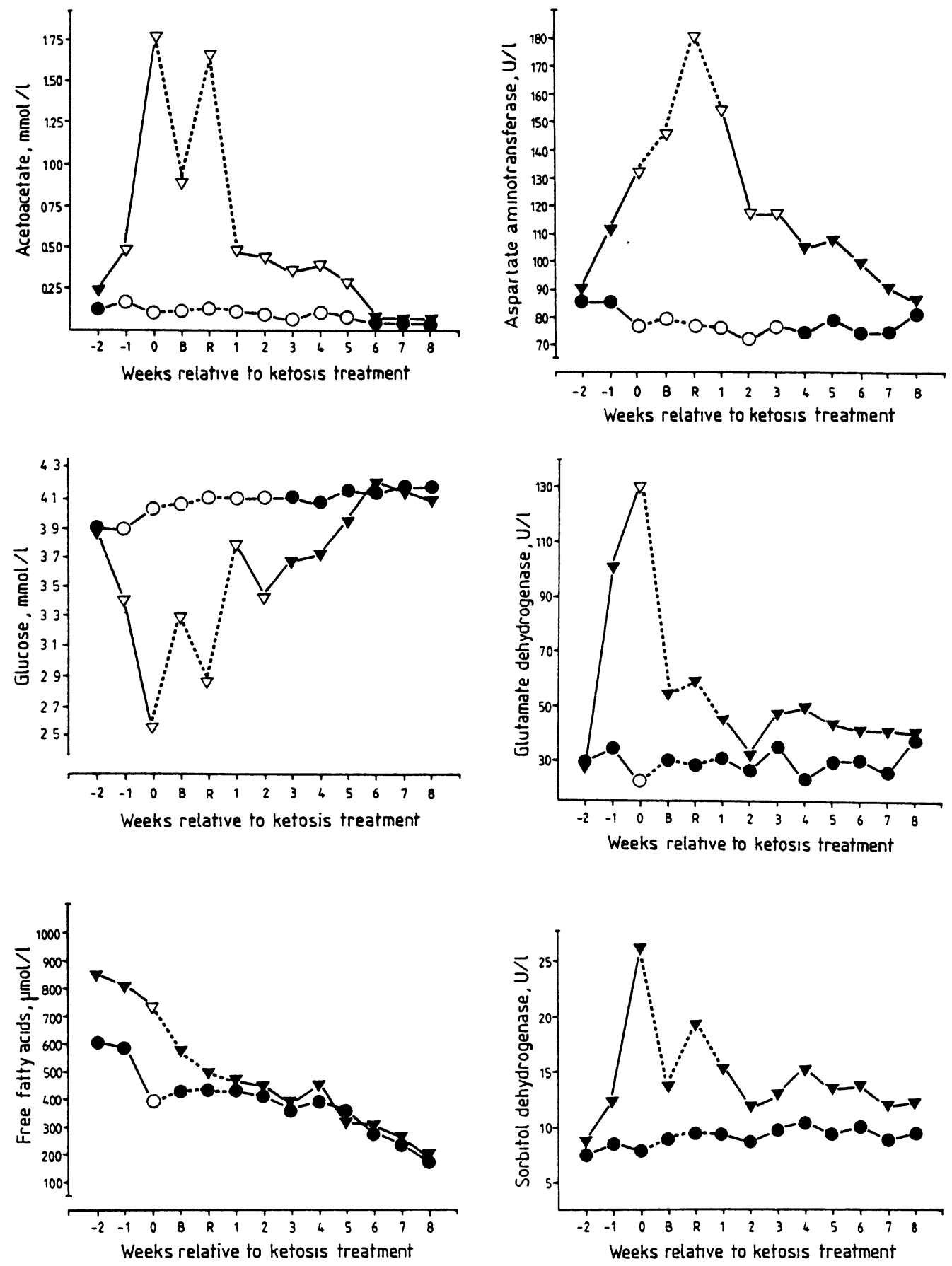

Acta vet scand vol 30 no $2-1989$ 

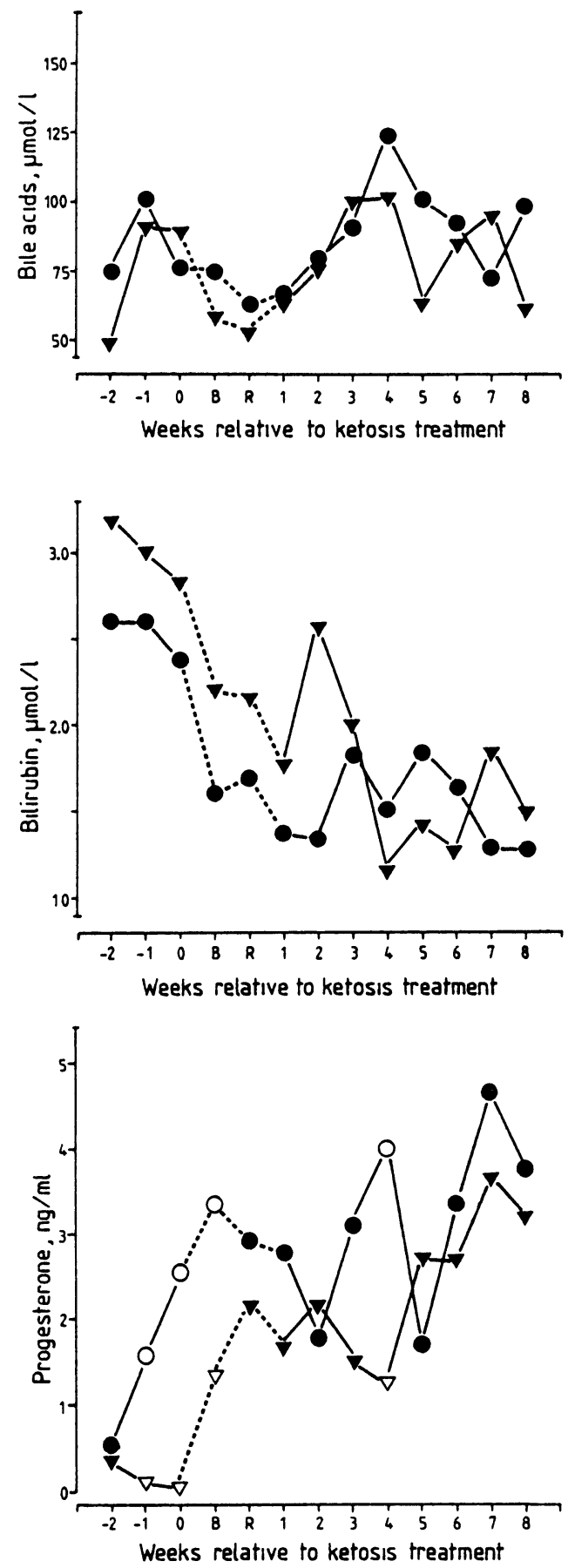

(ASAT, GLDH, SDH, BA, BILI) and ACAC were $0.21(\mathrm{p}<0.01), 0.14(\mathrm{p}<0.05), 0.06$ (n.s.), -0.03 (n.s.) and $0.38(\mathrm{p}<0.001)$, respectively. ACAC being significantly correlated with GLUC and FFA $(r=-0.75, \mathrm{p}<$ 0.001 and $r=0.53, p<0.01$, respectively). The within-animal coefficients of correlation between the liver enzymes were high, $r=0.53$ (ASAT/GLDH), $r=0.49$ $(\mathrm{GLDH} / \mathrm{SDH})$, and $r=0.53$ (SDH/ASAT), all significant at $\mathrm{p}<0.001$.

Metabolic status as indicated by the levels of ACAC explained only a minor proportion of the total variation of GLDH, SDH, BA, ASAT and BILI (Table 2).

\section{Reproductbility of differences between individuals}

Significant correlations were obtained for several parameters when averages obtained for the same individuals before partus and after day 70 post partum were compared. The correlation coefficients were $0.62(\mathrm{p}<$ $0.001), 0.66(\mathrm{p}<0.001), 0.38(\mathrm{p}<0.05)$ and 0.21 (n.s.) for GLUC, ASAT, SDH and GLDH, respectively. Exclusion of the heifers from the analysis did not result in any reduction in the coefficients of correlation. Although the variance contributions were low, significant interrelationships were also found between the same parameters before and after calving by variance analyses which included measurements from the first 3 months of lactation (Table 2). On the other

Figure 1. Weekly mean values of ACAC, GLUC, FFA, ASAT, GLDH, SDH, BA, BILI and PROG. Seven cows with ketosis $(\nabla-\nabla)$ and 14 multiparous cows which did not develop ketosis $(\mathrm{O} \longrightarrow$ ). Time scale in weeks before or after ketosis treatment, controls at the same average stages post partum as the diseased animals. Observations at first treatment $(\mathrm{O})$, between treatments (B) and during relapse (R). Mean values with open symbols differ significantly $(p<0.05)$. 
hand, pre-calving averages for the parameters concerned were practically identical in cows which developed ketosis and the multiparous controls.

\section{Liver fat and BSP-test}

The estimated volume density of liver fat in the 4th week of lactation averaged $6.0 \pm$ $6.4 \%$ ( \pm SD), ranging from $0.1-25.1 \%$. The BSP $1 / 2$ in plasma at the same stage of lactation averaged $3.6 \pm 0.7$ minutes $( \pm S D)$, ranging from $2.4-5.3 \mathrm{~min}$. No significant correlations were found between the percentage of liver fat and BSP $1 / 2$ on the one hand, and indicators of metabolic status (ACAC, GLUC and FFA) and liver function (ASAT, GLDH, SDH, BA and BILI) on the other. The volume density of liver fat averaged $2.3 \%, 4.0 \%$ and $8.3 \%$ in cows treated for ketosis, heifers and multiparous controls, respevtively $(\mathrm{p}>0.05)$.

\section{Plasma constituents. Comparison of ketotic and healthy animals}

He- and Le-controls differed significantly only with regard to ACAC, GLUC, FFA and BILI during the first 8 weeks of lactation (Table 1). In cows treated for ketosis $(n=7)$, significant increases in the levels of ASAT, GLDH and FFA were seen at the stage of first treatment. The ASAT average remained high for a prolonged period after treatment (Fig. 1). BA and BILI were not significantly related to time distance from ketosis treatment. The mean levels of SDH increased at first treatment, though not significantly ( $p>$ 0.05) (Fig. 1).

There was a considerable overlapping of ranges for all enzymes (ASAT, GLDH and SDH) between treated and control cows. At the time of first ketosis treatment, the proportion of observations with values higher than one standard deviation above the averages in control cows were $66.7 \%, 50.0 \%$ and $50.0 \%$ for ASAT, GLDH and SDH, respectively. The limits being ASAT; 93 $\mathrm{U} / 1, \mathrm{GLDH} ; 61 \mathrm{U} / \mathrm{L}$, and SDH; $13.9 \mathrm{U} / 1$. Similarly, $71.4 \%$ of the ASAT values obtained during the first 2 weeks after ketosis treatment and $78.5 \%$ of the values obtained during week 5 and 6 after treatment exceeded the chosen limit. The corresponding figures for GLDH were $21.4 \%$ and $28.5 \%$, respectively, and for SDH $35.7 \%$ and $35.7 \%$. In the period after ketosis treatment only the ASAT percentages differed significantly $(p<0.05)$ from those in control cows.

Although average values for ASAT, GLDH and SDH during the period from calving until 70 days after calving were significantly higher in relapsed cows than in cows requiring only a single treatment, that for ACAC was not (average values were: 138 and $92.9 \mathrm{U} / 1$ for ASAT, $\mathrm{p}<0.001 ; 74$ and $25 \mathrm{U} / 1$ for GLDH, p < 0.003; 17 and $9 \mathrm{U} / 1$ for SDH, $\mathrm{p}<0.05 ; 0.52$ and $0.42 \mathrm{mmol} / 1$ for ACAC, $p>0.10$ ).

\section{Reproductive performance}

Both the calving to first service interval and the time elapsing before PROG values reached $3 \mathrm{ng} / \mathrm{ml}$ were longer in ketotic cows than in multiparous controls ( $p<0.05$ and $p=0.10$, respectively) (Table 3 ).

The frequency of PROG values $>3 \mathrm{ng} / \mathrm{ml}$ was significantly lower in ketotic cows and heifers than in multiparous controls during the period from 3-5 weeks after calving, but not in later stages (Table 4), and progesterone values in ketotic cows were significantly lower than control values at the time of first ketosis treatment (Fig. 1).

The coefficients of correlation between the 0-60 days post partum averages of GLDH and SDH and the time distance from calving to PROG $>3 \mathrm{ng} / \mathrm{ml}$ were 0.64 ( $p<0.001$ ) and $0.45(\mathrm{p}<0.05)$, respectively. No other 
Table 3. Fertility in cows with ketosis compared with multiparous controls and heifers.

\begin{tabular}{llll}
\hline & \multicolumn{3}{c}{ Mean values, days 1$)$} \\
\cline { 2 - 3 } Fertility & \multicolumn{3}{c}{ Multiparous } \\
criteria & Heifers & controls & Ketosis \\
\hline
\end{tabular}

Time distance

from calving to:

\begin{tabular}{lccr} 
First oestrus & $54^{\mathrm{a}}$ & $64^{\mathrm{a}}$ & $58^{\mathrm{a}}$ \\
First service & $55^{\mathrm{c}}$ & $73^{\mathrm{a}}$ & $80^{\mathrm{b}}$ \\
Conception & $73^{\mathrm{a}}$ & $89^{\mathrm{a}}$ & $100^{\mathrm{a}}$ \\
Progesterone & & & \\
$>3 \mathrm{ng} / \mathrm{ml}$ & $62^{\mathrm{a}}$ & $43^{\mathrm{a} 2)}$ & $55^{\mathrm{a}}$ \\
\hline
\end{tabular}

1) Means with different superscript differ significantly $(p<0.05)$.

2) $\mathrm{p}=0.10$ for the difference between multiparous controls and cows with ketosis.

significant correlations between blood characteristics and reproductive parameters were found. In heifers, the onset of ovarian activity occurred later than in the multiparous controls, though fertility was good after resumption of ovarian activity.

\section{Discussion}

The ACAC and GLUC values observed in the experimental animals during ketosis (Fig. 1) corresponded closely to findings from field cases of the disease in this country
(Dale 1978). As in the field, cases arose mainly during the first month of lactation, seemingly causally related to a low supply of feed energy during initiation of lactation. Metabolic adaptation to underfeeding was indicated by the gradual changes in metabolite levels after ketosis treatment seen from the first to the third month af lactation in Fig. 1 (decreasing ACAC and increasing GLUC) while concentrate allowances remained low.

Comparing averages for the ketosis group and the equally underfed Le controls in Table 1, the impression is gained of individual differences in susceptibility to ketosis. A more robust roughage appetite may possibly have protected the healthy Le-cows against clinical ketosis (Table 1). The differences in metabolite levels shown in the same table between the Le and $\mathrm{He}$ groups are otherwise evidence of the occurrence of subclinical ketosis among the underfed animals.

Judged by the FFA curves in Fig. 1, fat mobilization does not seem to have been excessive in the cows with ketosis. The deviation from the control levels (He and Le cows combined) was significant only at the time of first ketosis treatment. If fat accumulation in the liver (Reid 1980) were a primary cause of ketosis in the present experiments, one

Table 4. Progesterone, frequency of values $>3 \mathrm{ng} / \mathrm{ml}$ in blood plasma low in cows with ketosis and in heifers during the first 5 weeks after calving.

\begin{tabular}{|c|c|c|c|c|c|c|c|}
\hline \multirow{3}{*}{ Anımal group } & \multirow{3}{*}{$\begin{array}{c}\text { Number of } \\
\text { anımals }\end{array}$} & \multicolumn{6}{|c|}{$\begin{array}{c}\text { Total number of observations and } \\
\text { percentage of progesterone values }>3 \mathrm{ng} / \mathrm{ml}\end{array}$} \\
\hline & & \multicolumn{2}{|c|}{ Week 3-5 } & \multicolumn{2}{|c|}{ Week 6-8 } & \multicolumn{2}{|c|}{ Week 9-11 } \\
\hline & & $\mathrm{n}$ & $\%$ & $\mathrm{n}$ & $\%$ & $\mathrm{n}$ & $\%$ \\
\hline Heifers & 6 & 41 & $12.2^{\mathrm{a}}$ & 42 & $23.8^{\mathrm{a}}$ & 36 & $58.3^{\mathrm{a}}$ \\
\hline $\begin{array}{l}\text { Multiparous } \\
\text { controls }\end{array}$ & 14 & 98 & $30.6^{\mathrm{b}}$ & 93 & $37.6^{\mathrm{a}}$ & 87 & $41.3^{\mathrm{a}}$ \\
\hline Ketosis & 7 & 49 & $10.2^{\mathrm{a}}$ & 49 & $32.6^{\mathrm{a}}$ & 42 & $33.3^{\mathrm{a}}$ \\
\hline
\end{tabular}

1) Frequencies within columns with different superscripts differ significantly $(\mathrm{p}<0.05)$. 
would have expected a greater difference in plasma FFA between ketotic and control animals in the post-partum period before treatment.

Some accumulation of liver fat is likely to have taken place (Gröhn et al. 1983) together with a depletion of liver glycogen coinciding with the minima in plasma GLUC at the times of ketosis treatment. Nevertheless, the condition must have been easily remedied, since no difference in fat content between ketosis and control animals could be detected by liver biopsy as early as in the fourth week post partum, when 6 of the ketosis patients had recently been treated with glucocorticoids. This negative result should be considered in conjunction with the absence of differences between categories of cows as regards BSP retention at the same stage of lactation. According to the literature, BSP clearance is delayed in cows with ketosis (Cornelius 1980).

Among plasma parameters with relation to liver function the greatest variance contribution from ACAC was found for ASAT (Table 2). This component also differed distinctly by giving an 8 -week average which was significantly higher for ketosis cows than for all 3 control groups in Table 1 . ASAT weekly averages for ketosis cows in Fig. 1 were consistently elevated from the time of the first treatment until the third week in the recovery period. For comparison ACAC was elevated until the fifth week of recovery.

According to Fig. 1, GLDH, SDH and ASAT all showed maxima during ketosis treatment. The fact that all 3 enzymes were inter-correlated with correlation coefficients as high as about 0.5 , indicates a common source of variation. This is of special interest for the discussion of the findings concerning ASAT, since this enzyme is less specific as a liver parameter than the 2 others. The re- sults concerning the 3 enzymes, considered together, provide evidence that there is some change in liver function or a certain degree of liver damage associated with clinical ketosis. Nevertheless, account must be taken of the extensive overlapping of ranges between ketotic and healthy cows, giving low levels of significance for GLDH and SDH in Fig. 1. As previously concluded by Pehrson (1966), liver lesions in ketosis appear to be mild.

Pehrson's conclusions were based on measurements of ASAT, ornithine carbamyl transferase (OCT), bilirubin and BSP retention. In contrast to Pehrson's results, significance was not obtained for the elevation of BILI at the time of ketosis treatment in the present study (Fig. 1). As seen in the figure, ketosis occurred at a time when BILI was declining from a post-parturient maximum even in control animals (large variance contribution from week of lactation in Table 2). The 8-week averages in Table 1 indicate that BILI is more strongly related to energy balance than to the severity of the ketonaemia. In spite of giving a significant withınanimal correlation to ACAC $(r=0.38, p<$ 0.001 ), BILI measurements seem to be of very limited value in the diagnosis of ketosis.

BA varied, seemingly unexplainably, within wide limits. In spite of this variability, a surprisingly good correspondence was obtained in the time-course of the BA average between ketotic animals and controls in Fig. 1. Apparently there is no relationship between ketosis and liver dysfunction which affects plasma levels of BA.

The present findings should be compared to those of Gröhn et al. (1983). Finding an increased content of fat in the liver at the time of ketosis treatment, these authors nevertheless concluded that a fatty liver was probably not a predisposing factor in most cases 
of spontaneous ketosis. They obtained a correlation between ASAT and SDH of the same magnitude as in the present study. However, in contrast to the results of the variance tests for the two enzymes shown in Table 2 (variance contribution from ACAC), they found that SDH was more strongly related than ASAT both to plasma ketones and to liver fat. Analogously, in the field material of Kauppinen (1984) OCT was found to exceed predetermined normal borderlines more frequently than ASAT in ketotic cows. Logically the borderline level for ASAT in large populations is influenced by the fact that the enzyme can be of extrahepatic origin. The significance obtained for ASAT in comparison to other parameters in the present study may thus be due to the exclusion of many sources of variation by the choice of individually fed, non-ketotic animals from the same herd as controls.

The frequent sampling of cows for prolonged periods, carried out in the present study, allowed the detection of reproducible individual differences with regard to several of the parameters measured. Attention is drawn to the significance of levels observed before calving as sources of variation of the same parameters measured after calving in Table 2 , and to the positive correlations obtained between measurements before calving and in the third month of lactation, both periods with consistently low ACAC levels. The natural question follows as to whether or not such more or less permanent differences between individuals within a normal range can reflect variations in liver function and in susceptibility to metabolic disease and ketosis. A seemingly negative answer is provided by the present study, since no difference was found between pre-partum averages in cows which subsequently developed ketosis and controls. Since the view has been advanced in the literature that liver damage suffered by cows before parturition may predispose for ketosis, it is of interest that evidence of such pre-parturient liver damage has not been observed in the present material. Infertility in cows as a consequence of impaired liver function has been suggested by several authors (Reid et al. 1979, Lotthammer 1982, Rowlands \& Reid 1982). Obviously, fertility disturbances affecting only a limited percentage of cows registrered as ketotic in the field cannot be confirmed in an animal material as small as in the present study. On the other hand, close observation of the sexual behaviour of experimental animals for as long as 3 month post partum might allow the detection of interrelationships which are likely to be overlooked in field studies.

As seen in Table 3, there was a significant prolongation of the post partum to first service interval in the cows treated for ketosis, though no confirmation of differences between groups of cows regarding the date of first oestrus and conception was obtained. Clearer evidence was obtained by comparing the twice-weekly progesterone measurements, low averages for PROG being obtained for ketosis cows until one week after treatment in Fig. 1.

Because of the large variation in PROG to be expected in the course of a normal ovarian cycle, a further test was performed (Table 4) on the frequency of values exceeding $3 \mathrm{ng} / \mathrm{ml}$ in successive 3 -week periods. Ketosis cows and heifers distinguished themselves by showing evidence of reduced luteal function until the fifth week post partum. The apparent short duration of the effect of ketosis on PROG should be considered in conjunction with the poor correlation obtained between PROG and ACAC by Benjaminsen (1977). Evidently, high levels of ACAC and low GLUC levels do not necessarily inhibit ovarian activity. A delay in the 
onset of ovarian activity in heifers compared to multiparous controls, as found in the present study (Table 4), is a common finding also under field conditions (Refsdal 1980).

No simple explanation can be given of the highly significant correlation obtained between GLDH mean and number of days from calving to the first registration of PROG $>3 \mathrm{ng} / \mathrm{ml}$.

Of interest for the interpretation of the present results, is the fact that the animals studied were under continuous veterinary surveillance. This could imply that ketosis treatments were generally given more promptly than is likely to be the case in the field, and this may have prevented more serious after-effects of ketosis on fertility performance. This may also be true of the effects of ketosis on liver-specific parameters.

\section{Acknowledgements}

The authors wish to thank H.P. Bugge and T. Landswerk for help with the preparation of the liver samples, and L.-W. Fredriksen, K. Edwardsen and $\mathrm{K}$. Edwardsen for excellent technical assistance.

\section{References}

Benjaminsen $E$. Progesteron og ovarialfunn i relasjon til plasma glukose og acetoacetat i postpartum-perioden hos ku. (Plasma progesterone and ovarian findings related to plasma glucose and acetoacetate in the post-partum period in the cow). Nord. Vet.-Med. 1977, 29, 337-342.

Benjaminsen $E$, Karlberg $K$. Post weaning oestrus and luteal function in primiparous and plur1parous sows. Res. Vet. Sci. 1981, 30, 318-322.

Blom AK, Halse $K$ : Corticosteroids in nocturnal blood plasma of cows in the field related to stage of lactation and plasma acetoacetate. Acta. endocr. (Kbh.) 1975, 78, 306-315.
Cornelius CE: Liver function. In: Clinical Biochemistry of Domestic Animals. Ed.: J. J. Kaneko. Academic Press, New York 1980.

Dale $H$. Feltgranskingar over ketose hjå mjølkekyr. (Field studies of ketosis in lactatıng cows). Thesis, Norwegian College of Veterinary Medicine, Oslo 1978.

Gröhn Y, Lindberg L-A, Bruss ML, Farver TB Fatty infiltration of liver in spontaneously ketotic darry cows. J. Dairy Sc1. 1983, 66, 2320-2328.

Hauge JG, Abdelkader $S V$ Serum bile acids as an indicator of liver disease in dogs. Acta vet. scand. 1984, 25, 450-503.

Kauppinen $K$. ALAT, AP, ASAT, OOT, OCT activities and urea and total bilirubın concentrations in plasma of normal and ketotic dairy cows. Zbl. Vet. Med. 1984, 31, 567-576.

Lotthammer $\mathrm{K}-\mathrm{H}$ Levels of some blood parameters as indicators for liver disorders - their causes, relations to fertility and possibility to prevent fertility problems. Proc. XII World Congr. Diseases of Cattle. 1982, 1, 527-532.

Pehrson BG. Studies on ketosis in dairy cows. Acta vet. scand. Suppl. 15, 1966, p. 1-59.

Refsdal AO. Fertiliteten hos ketosekyr. (Fertility in ketotic cows). Norsk Vet.-T. 1977, 89, 219221.

Refsdal $A O$. Ovarialfunksjon hos ku de første måneder etter kalving. (Post-partum ovarian function in dairy cows). Norsk Vet.-T. 1980, 92, 359-367.

Reid IM. Incidence and severity of fatty liver in dairy cows. Vet. Rec. 1980, 107, 281-284.

Reid IM, Roberts CJ Manston $R$. Fatty liver and infertility in high-yielding darry cows. Vet. Rec. 1979, 104, 75-76.

Roberts CJ, Reld, IM, Rowlands GJ, Patterson A A fat mobilization syndrome in dairy cows in early lactation. Vet. Rec. 1981, 108, 7-9.

Roine $K$, Saloniem $H$. Incidence of infertlilty in dairy cows. Acta vet. scand. 1978, 19, 354367.

Rowlands GJ, Reld IM. The link between fatty liver, blood metabolites and fertility in dairy cattle. Proc. XII World Congr. Diseases of cattle 1982, 1, 533-536. 
Saarinen P, Shaw JC Studies on ketosis in dairy cattle. XIII. Lipids and ascorbic acid in liver and adrenals of cows with spontaneous and fasting ketosis. J. Dairy Sc1. 1950, 33, 515525.

SAS (Statistical Analysis System). SAS User's Guide: Statistics. SAS Institute Inc., Cary N. C., 1982.

\section{Sammendrag}

Varıasjoner 1 leverfunksjonsparametre og plasma progesteron 1 relasjon til plasma acetoacetat $l$ de tre forste laktasjonsmåneder $\mathrm{l}$ en melkekubesetning med høy insidens av ketose

Tjueåtte NRF-kyr ble gitt silo etter appetitt og kraftfôr under norm. Blodprøver ble tatt før morgenfôrıng, 1 til 2 ganger ukentlig i perioden fra 2 uker før forventet kalving tıl 12 uker etter kalvıng. Leverbiopsier ble tatt i 4 . laktasjonsuke. Indikatorer på leverfunksjon, karbohydratstatus og fruktbarhet ble registrert og relatert til hverandre.

Åtte kyr fikk klınısk ketose, 4 ble behandlet 2 eller 3 ganger. Aspartat aminotransferase og bilirubin viste de høyeste innen dyr korrelasjoner til acetoacetat. Variansanalyse viste en signifikant effekt av karbohydratstatus (Indikert ved plasma acetoacetat) på nivåene av aspartat aminotransferase, glutamat dehydrogenase og sorbitol dehydrogenase, men bare en liten del av den totale variasjon i enzymaktıvitet ble forklart ved karbohydratstatus. Gjennomsnittlig fettprosent 1 leveren 14 . laktasjonsuke var $6.0 \pm 6.4 \%( \pm \mathrm{SD})$ (variasjonsområde: $0.1-25 \%)$ og fettprosent var ikke korrelert med andre leverparametre eller indikatorer på karbohydratstatus. Kyr som ble behandlet for ketose hadde lave progesteronverdier ved tıdspunktet for ketosebehandlıng. Frekvensen av høye progesteronverdier (> $3 \mathrm{ng} / \mathrm{ml}$ ) var signifikant lavere hos ketosekyr enn hos kontrollkyr i perioden fra 3 tıl 5 uker etter kalving, men ikke i seinere stadier.

Resultatene viser at det er en sikker men relativt svak sammenheng mellom karbohydratstatus og leverfunksjon. Klinısk ketose hadde en negatıv virkning på lutealfunksjonen.

(Recelved March 23, 1988; accepted August 18, 1988)

Reprints may be requested from: Erik Ropstad, Norwegian College of Veterınary Medicine, P. O. Box 8146 Dep., N-0033 Oslo 1, Norway. 
